\title{
Н.С. Коровина
}

\section{Отражение миграционных процессов в коми фольклоре}

\begin{abstract}
В данной статье сделана попытка рассмотреть роль миграционных прочессов в Коми крае (в частности, отходничества) в формировании и развитии таких жанров коми фольклора, как народная сказка и лирическая песня. Главными источниками статьи стали труды ученых, архивные материаль.
\end{abstract}

Ключевые слова: миграционные процессы, отходничество, коми народная сказка, лубочная литература, необрядовая лирика,частушка

\section{N.S. Korovina}

\section{Reflection of migration processes in the Komi folklore}

In this article the attempt to consider a role of migration processes in the region of Komi (in particular otkhodnichestvo) in formation and development of such genres of the Komi of folklore as the national fairy tale and the lyrical song is made. Works of scientists, archival materials became the main sources of article.

Key words: migration processes, otkhodnichestvo, Komi national fairy tale, primitivistic style literature, not ceremonial lyrics, chastushka

В конце XX - начале XXI в. огромное внимание российской общественности вызывают демографические процессы в различных регионах страны. Неудивителен поэтому и растущий интерес к этнодемографической проблематике в историко-культурной ретроспективе. Как отмечается в работах И.Л. Жеребцова, «изучение демографических процессов играет существенную роль для исследования всех аспектов истории и современного состояния каждого народа или региона, для прогнозирования условий его дальнейшего развития, поскольку движение и состав населения оказывают огромное воздействие на экономическую, социальную, политическую и культурную сферы жизни социума» $[1,15]$.

В социально-экономической жизни Коми края в конце XIX - начале XX в. заметное место занимал особый вид трудовой миграции населения - отходничество. Отхожий промысел получил широкое распространение в связи с проникновением в этот регион капиталистических отношений и принял устойчивый и массовый характер. Однако отходничество - это не только «особый вид трудовой миграции населения и особая модель экономического поведения. Это и новый образ жизни отходников, изменившийся политический статус этих людей, потенциал этих людей как новых «культуртрегеров» для своих местных обществ» [2, 35].

С характерным для Коми края явлением массового отходничества, особенно в XIX в., тесным образом связаны и судьбы коми фольклора. Поскольку на первых порах отходник еще теснейшим образом был связан со своим крестьянским хозяйством, крестьянская идеология, крестьянские формы ее выражения, в том числе и фольклор, занимали в его сознании первостепенное место. Русские сказки, русские песни, а позднее и частушки заняли прочное место в коми фольклорном репертуаре не без участия отходников.

Цель данной статьи - выявить роль миграционных процессов в формировании и развитии жанров коми фольклора. Рассмотрен этот процесс на основе анализа двух фольклорных жанров: сказки и необрядовой лирической песни.

Коми народная сказка - одна из самых богатых разделов фольклорного наследия коми народа. Собранный фольклорный материал свидетельствует о развитой сказочной традиции, об одаренных исполнителях народных произведений.

Общеизвестно, что сказка является одним из наиболее проницаемых жанров фольклора. Для нее не существует ни географических, ни территориальных границ. Интересные сведения, какими путями попадала сказка на Мезень, сообщил Ф.В. Плесовскому один из его исполнителей - А.С. Селиванов. Когда-то очень давно отец исполнителя после неурожайного лета отправился со своим соседом на заработки «добывать хлеб». Занимались пилкой дров и другими делами. На обратном пути, проезжая вычегодские деревни, попали к одному старику, сказками которого они заинтересовались. И только за то, чтобы старик продолжал

\footnotetext{
* Коровина Надежда Степановна (Сыктывкар) - кандидат филологических наук, старший научный сотрудник сектора фольклора ИЯЛИ Коми НЦ УрО РАН; e-mail: nadezhdakorovina@mail.ru
} 
рассказывать сказки, они пилили ему двое суток дрова. Вернулись они весной без лошади, в санках волокли ее шкуру, но зато с запасом сказок [3, 492].

Сказки рассказывались, разносились разного рода странствующими сельскими ремесленниками: катанщиками, пимокатами, портными. В нижневычегодской и сысольских волостях Коми края, например, заготовление валяной обуви имело существенное распространение. Катанием обуви занимались исключительно по заказу и из материала заказчика. Из-за недостатка сырья для катания этот промысел был преимущественно отхожим. Уходили в Вятскую, Пермскую, Оренбургскую, Тобольскую губернии или же в другие волости, преимущественно северные, в своих уездах.

По сведениям И.А. Осипова, известный сказочник с. Большелуг Ф.Т. Мишарин знал сказки с детских лет, научился рассказывать их, когда ездил заниматься валянием [4, 253]. О сказочнике с. Корткерос Е.Д. Ладанове исследователь пишет: «... 36 туй ветлӧма заводӧ; заводъясӧ ветлігӧн и медсясӧ велавлӧма мойдны, ӧтилысь да мӧдлысь» $[5,252]$ - «... 36 раз ездил работать на заводы; во время поездок на заводы и научился рассказывать сказки, от одного да от другого».

К числу известных мастеров-исполнительниц следует отнести А. А. Шуктомову. Репертуар талантливой сказительницы не только велик, но и исключительно многообразен. За 16 лет А. К. Микушев записал от нее около 50 сказок. В 1980 г. вышел сборник А. К. Микушева «Ипатьдорса фольклор» (Фольклор села Ипатово, 1980), посвященный талантливой коми сказительнице. Он является пока единственным коми фольклорным изданием, где рассматривается творчество отдельного исполнителя. Во вступительной статье дается творческий портрет А. А. Шуктомовой. Кроме сказок А.К. Микушев записал от нее 100 песен, 60 причитаний, 150 частушек. В ее памяти хранится также громадный запас загадок, пословиц и поговорок. На всю округу она славилась как искусная плакальщица, знает не только свадебные, но и похоронные, рекрутские причитания. Причитать выучилась в своей деревне - еще в девушках. По рассказам, жизнь ее была не из легких. Работала прислугой, уборщицей. Вместе с мужем неоднократно ездили за Урал на отхожие промыслы, заготавливали лес, работали там на сплаве. Все это время она рассказывала сказки, узнавала там новые сюжеты сказок [6, 10].

В общем сказочном фонде коми народа имеется довольно большой пласт сказок, тесно связанный с русской книжной традицией, в основном с лубочной литературой. Она поступала в Коми «и через офеней во время ярмарок, книгами наряду с другими товарами торговали купцы, их привозили возвращающиеся из отхожих промыслов крестьяне, студенты и учащиеся...» [7, 83].

Лубочной книгой исследователи обычно называют дешевые массовые издания для народа, появившиеся в России во II половине XVIII в. Ее название «лубочный», по мнению большинства исследователей, происходит от названия лубочных листов, или лубков - картинок примитивного содержания с поясняющим текстом, напечатанных с «лубка», т.е. с липовой гравировальной доски, которой пользовались русские печатники в XVII и начале XVIII в. [8, 8-9]. Вслед за лубочными картинками во второй половине XVIII в. появились лубочные книжки, в которых остался лишь текст, а картинки украшали обложки или печатались как иллюстрации.

Первоначально основным содержание этих книжек были жития святых (жития Николая-чудотворца, Марии Египетской), различные поучения, например, о вреде пьянства и брани, о неотвратимости Страшного суда. Постепенно значительное место в этих изданиях начали занимать легенды, былины, исторические сказания, сказки. Большой популярностью пользовались авантюрные рыцарские повести о Бове-королевиче и Еруслане Лазаревиче, «История о храбром рыцаре Францыле Венциане и о прекрасной королеве Ренцивене», повесть «Гуак, или Непереоборимая верность», проникшие на Русь еще в XVI-XVII вв.

Некоторые издатели лубка (И.Д. Сытин, Е.А. Губанов, А.А. Холмушин и др.), завлекая потенциальных покупателей, старались максимально снизить отпускные цены своих книг (для этого использовалась самая низкопробная серая бумага), а низкое полиграфическое качество компенсировалось яркой обложкой с выразительными изображениями главных героев и заголовками, которые сразу бросались в глаза.

В настоящее время в коми фольклорном фонде имеются записи восьми вариантов сказок о Бовекоролевиче, шести - о Еруслане Лазаревиче, семи - о Портупее-прапорщике и одного варианта - об Английском Милорде.

Необходимо отметить, что влияние лубочной литературы было в основном, конечно, опосредованным, сюжет усваивался со слов другого сказителя, знавшего произведение из книги. По словам слепого удорского сказочника И.И. Игушева, сказку о Еруслане Лазаревиче он перенял от коми исполнителя И.К. Федорова, прочитавшего книгу об этом герое, во время работы на лесопильном заводе в с. Каменка Архангельской области.

Однако нельзя исключить и возможность непосредственного усвоения грамотными исполнителями сказок из лубочных изданий. По сведениям исследователей, уже в XVIII в. коми население было двуязычным, что сыграло немаловажную роль в усвоении сказок $[9,137]$.

Сказки о Бове-королевиче и Еруслане Лазаревиче, записанные Ф.В. Плесовским в 1957 г. в с. Ужга Койгородского р-на от Ф.Е. Попова [10, 486 об.-497 об.], характеризуются довольно точным пересказом со- 
держания лубочной сказки (в позднейших его обработках). Имена главных действующих лиц, например, фигурируют в нем без серьезных изменений. Можно предположить, что здесь не исключена возможность непосредственного усвоения исполнителем сказки из лубочных книг. К сожалению, собиратели фольклора не оставили никаких данных ни о личности сказочника, ни об источниках усвоения анализируемых сюжетов.

Отхожие промыслы стали одним из путей обогащения и коми песенного репертуара. Отходники возвращались в родные края с пустыми карманами, не забыв однако «прихватить» с собой новую модную песню или песню, сложенную такими же, как и они, отходниками. Сохранились даже конкретные указания о том, откуда была воспринята та или иная песня. Известно, что вымская молодежь часто шла на отхожие промыслы в Вятку. А.К. Микушеву удалось записать в д. Увдор Усть-Вымского р-на в 1964 г. русскую песню «Как у нас во мастеровой». Песня эта была сложена мастеровым людом в Вятке и завезена коми отходниками на Вымь $[11,82]$.

B XIX - начале XX в. в коми устном творчестве формируется новый вид песенной лирики, стоящий на грани традиционных песен и частушечной поэзии. И родился он именно на рубеже двух веков, т.е. вслед за рождением нового частушечного жанра и в русском фольклоре.

Причем эти песни, по мнению А.К. Микушева, «Родились в тот момент, когда в коми деревне получило массовый характер отходничество, когда процесс классового расслоения в коми деревне стал особенно интенсивным. Именно отходничество явилось той основной социальной средой, в которой родился новый фольклорный жанр - частые песни-воспоминания и частушки. Именно отходники, наиболее мобильная часть коми населения, имели большие возможности первыми уловить новые веяния в русской народнопесенной культуре и под влиянием новых жизненных впечатлений создать свое отличное художественное творчество» $[12,11]$.

Основным создателем и потребителем таких песен была среда отходничества. Тема социальной несправедливости, торга, найма рабочей силы отчетливо стала звучать в коми песнях позднего происхождения, бесконечно варьируясь от песни к песне. В текстах некоторых песен отразились даже два термина отходничества. «Гуляйтӧм» - так говорили, когда отходник отправлялся на заработки на одну зиму, на один сезон. «Зимогоритӧм» - так называли отходников, уходивших на промыслы на несколько лет.

Часто в новых песнях и частушках упоминался Богословский завод: «Кытчӧ сійӧ мунӧма? - Богословӧ мунӧма! - Мыйла сійӧ мунӧма? - Брукила, колошила!» (Куда он отправился? - В Богослов отправился. - Зачем он туда отправился? - За брюками, калошами) $[13,110]$.

Богословский завод, построенный в 1770 г., к началу XX в. имел две церкви, богодельню, 8 тыс. жителей и множество пришлого люда - углежегов [14, 464-468]. Вот как писал о положении коми отходников на уральских отхожих промыслах Василий Немирович-Данченко: «Выносливость их (зырян. - Н.К.) выше всякого сравнения. Они вбивают в землю четыре низеньких столба, настилают на них крышу. Со всех сторон открыто. Под таким катафалком они спят в снегу месяцы, какие бы морозы ни стояли. Дров для себя не изводят; едят иногда сырое, например, соленую рыбу. Замерзают редко, хотя разумеется, и этот грех случается» $[15,292]$.

Вот в таких каторжных условиях приходилось жить тысячам вычегодских и сысольских отходников. «Коньӧрӧй да ратникӧй» (Горемыка-ратник), «Коньӧро̋й да Ванькаӧй» (Горемыка-Ванька), «Коньӧрӧй Падласовӧй» (Горемыка Падласов). В этих песнях отношение к отходнику выражено сразу в зачине песни, в главном эпитете, которым награждается отходник «коньӧр» (бедный, бедняжка, горемычный).

И всегда подчеркнуто поданы картины безысходности бедняка. В песне «Кор ме вӧлі кык арӧса» (Когда я был двухлетним), записанной от бывших отходников, которые искали счастья на уральских заводах, на кажимских и ярославских промыслах, сказано:

Кажим заводӧ пыри, На Кажимский завод нанялся,

Куим во нажевитчи... Три года зарабатывал...

Богословыс кӧ ылын, Богослов-то далеко,

Ярославыс ылынджык.

Богословас кӧ сьӧкыд, В Богослове тяжело,

Ярославас сьӧкыджык... В Ярославле тяжелей... [16, 111].

Мотив безысходного горя не забыт верхневычегодскими певцами, которые замечают:

Унмӧ кайны - пос абу,

Муӧ пырны - розь абу, Скрыться в землю - нет дыры,

Ваё пыран - пӧдан, $\quad$ В воду сунешься - утонешь,

Уна вожа туй мунӧ, Много есть путей - дорог,

Толькӧ менам туй абу... Только мне дороги нет... $[17,8]$. 
Главным героем новых песен был коми отходник, молодой парень, безуспешно пытающийся выбиться в люди, наладить собственное хозяйство при помощи отхожего промысла. Чаще образ отходника раскрывается «со стороны», обычно от имени его возлюбленной «Менам милӧйо̆й абу» (Милого моего нет), «Менам рытъянӧй абу» (Моего друга на вечеринке нет), «Ме кӧ петі рытйысьны» (Как-то вышла на посиделки).

Ме кӧ петі рытйысьны,

Как-то вышла на посиделки,

Менам друганӧй из во, Мой друг не пришел,

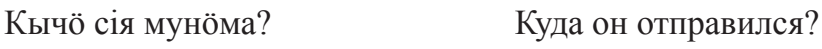

Питимбургӧ мунӧма.

Мыйла бара мунӧма? Зачем он туда отправился?

Машинала мунӧма. З За машинкой отправился.

Мый машинанас карӧ? Зачем нужна машинка?

Кашемир кӧшель вурӧ, Кашемировый кошель сшить,

Еджыд сарапан кӧрӧ. Белый сарафан сшить [18, № 154].

Молодая девушка создает эмоционально-окрашенный портрет отходника:

Яран ты дорӧ ветлі, К ненецкому озеру ходила,

Роч казакӧс аддзылі, Русского казака повстречала,

Зелезеньӧн зипунӧн, В В зелезеневый тулуп одет,

Визьӧн кушакӧн, Полосатым кушаком подпоясан,

Кукань ку да кепысьӧн, Рукавицы из телячьей кожи,

Баля ку шапкаӧн, Шапка из овечьей шкуры,

Тугъя, тугъя да вӧньӧн. Пояс с кисточками [19, № 449].

Таков традиционный портрет отходника. В портретной характеристике отходника появляются детали нового фабричного костюма с обязательным реквизитом из калош, «сертука» (сюртука), «роч ной гач» (брюк из русского, т.е. фабричного, не самотканого сукна).

Каля ты дорӧ ветлі-а

Роч казаксӧ аддзылі,

К Каля озеру я ходила,

Русский там стоит казак,

Визя кушака,

Роч ной пальтоа,

В полосатом кушаке,

В пальто из тонкого сукна,

Визя еджыд дӧрӧма.

Галипея гача,

В рубашке белой в полоску.

Кромӧвей сапӧга да,

Бобровка-шапка юрас.

В брюках галифе,

В хромовых сапогах,

На голове бобровая шапка $[20,72]$.

Нарядный щеголь, одетый в новые суконные брюки и в камаши с галошами, постоянно привлекал воображение бедноты. Такой щеголь, которому удалось скопить деньги, казался особенно счастливым парнем. Обычно отходники возвращались без гроша в кармане, постоянные штрафы и поборы выматывали их вконец.

Большая мобильность коми населения, широкое распространение отходничества способствовали активному появлению новых сказочных и песенных сюжетов в Коми крае, в том числе и новых песенных жанров песен-частушек. Все это привело к обогащению коми национального фонда новыми сюжетными типами и версиями сказочных и песенных сюжетов и сюжетных типов. Русская сказка и русская песня органично вошли в коми устную фольклорную традицию. Этому способствовали давние коми-русские культурные связи и развившееся активное двуязычие.

\section{Источники и литература}

1. Жеребиов И.Л. Коми край в XVIII - середине XIX века: территория и население. Сыктывкар: изд-во Коми НЦ УрО PAH, 1998. $174 \mathrm{c}$.

2. Плюснин Ю.М., Позаненко А.А., Жидкевич Н.Н. Отходничество как новый фактор общественной жизни // Новый мир. Научный журнал. 2015. № 1. С. 35-71.

3. Ф.В. Плесовский. Удорские сказочники // Сказки народа коми. Коми мойдъяс / Сост. Н.С. Коровина. Сыктывкар, 2009. C. 489-493.

4. Висер вожса сьыланкывъяс да мойдкывьяс (Песни и сказки Вишеры) / Сост. И.А. Осипов. Сыктывкар, 1941. 236 с.

5. Висер вожса сьыланкывъяс да мойдкывъяс (Песни и сказки Вишеры) / Сост. И.А. Осипов. Сыктывкар, 1941. 236 с.

6. Ипатьдорса фольклор (Фольклор села Ипатово) / Сост. А. К. Микушев. Сыктывкар, 1980. 184 с.

7. Рощевская Л.П., Ярошенко М.А. Издания И.Д. Сытина в Коми крае // Источники по истории народной культуры Севера. Сыктывкар, 1991. С. 77-83.

8. Корепова К.Е. Русская лубочная сказка. Н. Новгород, 1999. 244 с.

9. Маиук М.А. Коми край от Бориса Годунова до Петра І. Сыктывкар, 1993. 184 с.

10. Научный архив Коми научного центра УрО РАН (далее - НАКНЦ). Ф. 1. Оп. 11. Д. 187. 
11. НАКНЦ. Ф. 1. Оп. 11. Д. 233а.

12. Микушев А.К., Чисталев П.И. Коми народные песни. 2-е изд. Сыктывкар, 1993. Т. І. 287 с.

13. Микушев А.К., Чисталев П.И. Коми народные песни. 2-е изд. Сыктывкар, 1993. Т. І. 287 с.

14. Урал. Северный, средний, южный. Справочная книга / Сост. Ф.П. Доброхотов. Петроград, 1917.

15. Немирович-Данченко Вас. Кама и Урал (Очерки и впечатления). СПб., 1890.

16. Микушев А.К., Чисталев П.И. Коми народные песни. 2-е изд. Сыктывкар, 1994. Т. II. 192 с.

17. Микушев А.К., Чисталев П.И. Коми народные песни. 2-е изд. Сыктывкар, 1993. Т. I. 287 с.

18. НАКНЦ. Ф. 1. Оп. 11. Д. $233 \mathrm{a}$.

19. НАКНЦ. Ф. 1. Оп. 11. Д. 233а.

20. Микушев А.К., Чисталев П.И. Коми народные песни. 2-е изд. Сыктывкар, 1994. Т. II. 192 с. 